\title{
Review \\ Molecular imaging as a tool for translating breast cancer science David A Mankoff
}

Seattle Cancer Care Alliance and University of Washington, Radiology, 825 Eastlake Avenue East, Seattle, WA 98109, USA

Corresponding author: David A Mankoff, dam@u.washington.edu

Published: 9 December 2008

Breast Cancer Research 2008, 10(Suppl 1):S3 (doi:10.1186/bcr2126)

This article is online at http://breast-cancer-research.com/content/10/S1/S3

(c) 2008 BioMed Central Ltd

\begin{abstract}
The ability to measure biochemical and molecular processes underlies progress in breast cancer biology and treatment. These assays have traditionally been performed by analysis of cell culture or tissue samples. More recently, functional and molecular imaging has allowed the in vivo assay of biochemistry and molecular biology, which is highly complementary to tissue-based assays. This review briefly describes different imaging modalities used in molecular imaging and then reviews applications of molecular imaging to breast cancer, with a focus on translational work. It includes sections describing work in functional and physiological tumor imaging, imaging gene product expression, imaging the tumor microenvironment, reporter gene imaging, and cell labeling. Work in both animal models and human is discussed with an eye towards studies that have relevance to breast cancer treatment in patients.
\end{abstract}

\section{Introduction}

The ability to assay cancer biological features is key to advances in both the basic and clinical science of breast cancer. Advances in our ability to assay molecular processes, including gene expression, protein expression, and molecular and cellular biochemistry, have fueled recent advances in our understanding of breast cancer biology and our ability to treat breast cancer in patients. Most assays require sampling of cells or tissues to perform the measurements. Thus, the cell culture system, animal model, or patient must be perturbed in order to perform the assay. This requirement makes serial assays over time more difficult and leaves open the possibility that the assay itself may change the state of the system being measured. The ability to measure biological processes without perturbing them would be highly desirable and would offer complementary information to that obtained by most traditional assay methods.

Advances in both technology and cancer science have led to the ability to perform non-invasive molecular assays. An example is the use of reporter genes whose expression results in the production of material such as green fluorescent protein or luciferase that can be detected without tissue sampling [1]. Another advance, applicable to the entire range of biological systems from cell culture to human, is molecular imaging $[2,3]$, which is the focus of this review.

Imaging has traditionally relied on structural and anatomic features to detect breast cancer and determine its extent [4]. This traditional form of imaging, often termed anatomic imaging, has made an important contribution to cancer care, and is widely used in the detection and staging of breast cancer patients using methods such as X-ray mammography and computed tomography (CT). More recently, imaging has expanded to include the ability to image regional biochemistry and molecular biology, often termed molecular imaging [2]. The focus for molecular imaging is not structure, but rather regional biology. Quantitative analysis is an important feature of this type of imaging, for example, the ability to measure regional tumor receptor expression $[5,6]$. As such, molecular imaging can be considered an in vivo assay technique, capable of measuring regional tumor biology without perturbing it. This makes molecular imaging a unique tool for probing breast cancer biology, complementary to traditional assay methods, and a potentially very powerful tool for translational science. In the sections that follow, imaging methods used in molecular imaging are reviewed, the biological processes that can be assayed are discussed, and selected examples of translational science using molecular imaging are reviewed. The focus is on in vivo imaging of animal models and patients.

It is important to keep in perspective inherent differences in capabilities between tissue-based assays and in vivo assays using molecular imaging. Imaging is non-invasive and, therefore, better suited to serial assay. In addition, imaging typically surveys the entire animal or patient and, therefore, avoids sampling errors that can occur for assays that require tissue sampling, especially when there is significant tumor heterogeneity. However, while sample-based methods can

$\mathrm{CT}$ = computed tomography; $\mathrm{DCE}=$ dynamic contrast enhanced; $\mathrm{ER}=$ estrogen receptor; FDG = fluorodeoxyglucose; FES = fluoro-17 beta-estradiol; FLT = fluorothymidine; FMISO = fluoromisonidazole; MR = magnetic resonance; MRI = MR imaging; MRS = MR spectroscopy; PET = positron emission tomography; PR = progesterone receptor; $\mathrm{SPECT}=$ single-photon computed tomography. 
Table 1

\begin{tabular}{|c|c|c|}
\hline Modality & Advantages & Disadvantages \\
\hline \multicolumn{3}{|l|}{ Magnetic resonance } \\
\hline Magnetic resonance imaging (MRI) & $\begin{array}{l}\text { High spatial resolution and image detail } \\
\text { Increasing range of contrast agents under } \\
\text { development }\end{array}$ & $\begin{array}{l}\text { Confined space } \\
\text { Contrast design limited by need for magnetic } \\
\text { atom }\end{array}$ \\
\hline Magnetic resonance spectroscopy (MRS) & $\begin{array}{l}\text { Can measure wide range of molecules } \\
\text { No contrast needed }\end{array}$ & $\begin{array}{l}\text { Limited spatial resolution } \\
\text { Challenging to get high quality spectra in routine } \\
\text { imaging }\end{array}$ \\
\hline \multicolumn{3}{|l|}{ Radionuclide imaging } \\
\hline Positron emission tomography (PET) & $\begin{array}{l}\text { Wide range of molecular imaging probes } \\
\text { Tracer imaging without perturbing biological } \\
\text { system }\end{array}$ & $\begin{array}{l}\text { Limited spatial resolution } \\
\text { Some radiation exposure }\end{array}$ \\
\hline $\begin{array}{l}\text { Single photon emission tomography } \\
\text { (SPECT) }\end{array}$ & $\begin{array}{l}\text { Similar to PET } \\
\text { Probes more widely available }\end{array}$ & Less quantitatively accurate than PET \\
\hline $\begin{array}{l}\text { Ultrasound, especially with contrast } \\
\text { enhancement }\end{array}$ & $\begin{array}{l}\text { Highly portable, inexpensive } \\
\text { Molecular microbubble contrast agents } \\
\text { possible }\end{array}$ & $\begin{array}{l}\text { Operator dependence } \\
\text { Contrast agents confined to vascular space thus } \\
\text { far }\end{array}$ \\
\hline Optical imaging & $\begin{array}{l}\text { Highly portable, inexpensive } \\
\text { High spatial resolution possible }\end{array}$ & $\begin{array}{l}\text { Limited penetration from surface, limited to } \\
\text { relatively superficial sites }\end{array}$ \\
\hline
\end{tabular}

assay many different processes at once - for example, the expression of an array of genes [7] - imaging can typically sample at most a few processes at the same time. Also, while it is possible to 'batch' process for many samples at the same time, imaging needs to be performed one subject at a time. Furthermore, the need for sophisticated equipment and imaging probes makes imaging typically more expensive than sample-based assays. These last two factors limit the number of subjects that can be studied by imaging compared to sample assays. In general, imaging methods are complementary to assay-based methods and best used to explore breast cancer biology in intact animal models or patients, or to image the effects of therapeutic intervention on in vivo tumor biology.

\section{Imaging modalities}

The imaging modalities most commonly used in molecular imaging are listed in Table 1. Common among these modalities is the ability to image functional and molecular tissue properties such as perfusion, metabolism, and receptor or oncogene expression [5,8-12]. This section provides a brief description of each modality, along with its advantages and disadvantages.

\section{Magnetic resonance imaging}

Magnetic resonance (MR) relies upon the interaction of atomic nuclei with radiofrequency signals in the presence of strong magnetic fields. MR imaging (MRI) offers high spatial resolution and functional contrast agents using magnetic elements such as Gd and Fe [10]. Breast MRI using non- specific contrast agents such ad Gd-DTPA has become an important part of clinical breast cancer [13], and there have been some notable recent successes in the use of breast MRI for breast cancer detection [14]. More detailed and quantitative approaches to dynamic contrast enhanced (DCE) breast MRI have been increasingly used to examine tumor perfusion and capillary permeability as an indicator of tumor angiogenesis [15-17]. More specific and targeted MRI agents have also been developed and undergone preliminary testing [18]; however, the range of possible molecular agents is somewhat constrained by the need to include a magnetically active atom such as Gd or Fe. Recent advances in pulse sequences and image acquisition have led to the ability to measure other tissue properties, such as water diffusion, that can provide information on cellularity and interstitial transport without the need for contrast $[19,20]$. An advantage of MRI is its high spatial resolution and image quality, especially with increasing magnetic field strength, making it applicable to both small animals and patient imaging. Limitations include the cost of the imaging system and the thus far somewhat limited range of imaging probes that serve as MR contrast agents, although new approaches tested in pre-clinical models will provide increased capabilities for animal research and may be able to be translated to patient studies [18].

\section{Magnetic resonance spectroscopy}

MR spectroscopy (MRS) takes advantage of the ability of nuclear magnetic resonance to identify specific chemical signatures and measures the regional concentrations of bio- 
chemical species, using methods similar to those developed for basic chemical assays [9]. Much of current work in patients uses hydrogen spectroscopy; however, spectroscopy for other biologically relevant nuclei, such as phosphorus or sodium, is also possible [21]. MRS can quantify the concentration of prevalent biochemical species without perturbing the system being imaged, and without the need for imaging contrast administration. MRS has considerably more limited spatial resolution compared to MRI; however, recent advances in magnetic field strength and MRS technology have yielded the ability to generate three-dimensional MRS concentration maps (MRS images, MRSI) with resolution on the order of $1 \mathrm{~cm}$ or less [9]. Recent studies suggest that changes in local metabolites with therapy may provide a very early indicator of breast cancer response [22]. MRS has the advantage of being able to directly quantify molecular species without the need for contrast, with the disadvantages of more limited spatial resolution and the need for relatively high abundance to be able to reliably quantify regional biochemical concentration. It shares the need for relatively expensive equipment with MRI, and in fact, requires fairly high field strength, typically 3T or more, to be effective for animal and patient breast studies [9].

\section{Radionuclide imaging}

Radionuclide imaging relies on the use of imaging probes, typically termed radiopharmaceuticals, tagged with radioactive nuclei [5]. Position-sensitive radiation detectors identify emitted photons and generate images of regional radiopharmaceutical concentration. This imaging approach, sometimes called nuclear medicine, has traditionally relied on gamma-emitters such as ${ }^{99 m T c}$ or ${ }^{131}$ to form images in a technique often termed single-photon computed tomography (SPECT)). Somewhat more recently, advances in both instrumentation and radiochemistry have led to the ability to image positron-emitting nuclei, such as ${ }^{11} \mathrm{C}$ and ${ }^{18} \mathrm{~F}$, in a wide range of molecules in an approach known as positron emission tomography (PET) [23]. Compared to SPECT, PET offers the potential for better spatial resolution, more accurate image quantification, and a wider range of possible imaging probes; however, both PET and SPECT have made notable contributions to breast cancer clinical care and research $[5,23,24]$. The chief advantage of radionuclide imaging is the ability to measure probe concentrations in the nanomolar, and even picomolar, range, leading to the ability to measure even the most sensitive molecular processes without perturbing them. A wide range of radiopharmaceuticals has been developed to image diverse aspects of breast cancer biology [25]. Disadvantages include more limited spatial resolution and the need to produce and distribute relatively short-lived imaging probes. Recent development in dedicated imaging devices for small animals [26] and breast-specific imaging [27] has overcome some of the limitations in spatial resolution; however, inherent spatial resolution is less than for other methods such as CT or MRI. The combination of PET or SPECT with X-ray CT (PET/CT or SPECT/CT) yields co- registered molecular and anatomic images and the opportunity to image molecular biology and anatomy simultaneously [28]. Radionuclide imaging probes and instrumentation are relatively expensive, with costs comparable to MRI.

\section{Optical imaging}

One of the oldest forms of imaging is optical imaging, using visible light to generate images. In many ways optical imaging is the earliest form of cancer imaging, in the form of light microscopy. Recent advances in instrumentation, computational algorithms, and imaging probes have led to new capabilities in optical imaging of living organisms, including small animal models and patients [29]. A variety of optical methods have been developed that can yield in vivo images with high contrast, and, in some cases, considerable detail, down to the microscopic level. Methods can measure regional biology such as vascularity and blood volume using inherent tissue optical properties [29], or take advantage of an ever increasing array of optical probes to image specific molecular processes [30]. Low cost, portability, ease of use, and wide availability of imaging probes are key advantages of optical imaging. Its chief disadvantage is relatively limited tissue penetration. Thus, while optical imaging has become an essential tool for breast cancer animal research [31], its use in patients has been more limited. While promising early studies in breast tumor imaging point towards future clinical application [29], optical imaging has been mostly confined thus far to the pre-clinical setting, where it is an important tool for breast cancer research.

\section{Ultrasound}

Ultrasound imaging works by using acoustical transducers to send and receive ultrasound frequency energy and generate three-dimensional images from either reflection or throughtransmission [8]. Conventional ultrasound provides highresolution anatomic detail, and breast ultrasound plays an important role in breast cancer diagnosis [32]. Doppler technology also provides information on tumor vascularity, and with the advent of microbubble contrast agents, tumor perfusion [33]. Recent advances in imaging technology [34] and the development of targeted microbubble contrast agents hold promise for molecular imaging [33]. The portability and relatively low cost of ultrasound make it an ideal tool for both animal and patient imaging, and the ability to measure molecular processes will make ultrasound a valuable tool for breast cancer research. Disadvantages include some operator dependence in image acquisition and interpretation, and some challenges in developing molecularly targeted micobubble contrast agents.

Other imaging modalities such as X-ray radiography and X-ray CT play an important role in structural imaging, but are more limited for molecular imaging. Dynamic contrast CT can be used to measure tissue perfusion, similar to DCE-MRI, with the disadvantage of relatively high radiation exposure. 
Other techniques are also being investigated [35], but are at relatively early stages of development and not discussed in detail here.

\section{Imaging assays: what can be measured?}

Molecular and functional imaging that can measure a range of cancer biological features have been developed and validated. These capabilities are reviewed in this section, broadly dividing categories of imaging assays into functional/physiological properties, protein expression (with an emphasis on tumor receptors), the tumor microenvironment, and tumor gene expression. Both applications to animal models [36] and patients [23] are reviewed.

\section{Functional physiological tumor properties}

Imaging is ideally suited to measuring in vivo tumor biology related to basic physiological properties such as perfusion, metabolism, biosynthesis, cell proliferation, and cell death. In fact, many of these processes are difficult to assay by tissue sampling; therefore, imaging provides a unique and quantitative measure of these properties that can only be measured in vivo.

Tumor perfusion is one of the earliest physiological properties to be measured, and advances in methodology have led to increasingly quantitative approaches. The most physiologically robust and quantitative measures of tumor blood flow use freely diffusible imaging probes, where blood flow can be inferred from the time course of probe uptake and washout, adapting methods developed for measuring cerebral blood flow [37]. One example is the use of ${ }^{15} \mathrm{O}$-water to measure tumor blood flow by PET, which yields measures of tumor blood flow in $\mathrm{ml} / \mathrm{minute} / \mathrm{g}$ that have been validated against microsphere methods [38]. Water PET imaging has been shown to be effective in monitoring breast cancer response, and changes in tumor perfusion with treatment measured by water PET are predictive of survival [39]. Diffusable optical probes may also be used for this purpose [29]. Considerable effort has been devoted to the quantification of tumor perfusion and tumor capillary permeability using radiographic and MRI contrast agents [40-44]. These agents have somewhat limited permeability across capillaries; therefore, their in vivo kinetics are dependent upon both blood flow and capillary permeability. Increasingly sophisticated image acquisition and analysis methods, for DCE-MRI in particular, have led to the ability to measure regional breast cancer perfusion and capillary permeability in both animal models and patients [17]. Novel MRI contrast agents, including macromolecular agents, may offer additional capabilities [45]. These methods have been applied in early trials of antiangiogenic therapy breast cancer and have yielded insights into the nature of response [16]. Standardized methods for DCE-MRI for clinical trials have been proposed [46].

Tumor perfusion imaging requires good vascular access for prompt and reliable delivery of the imaging probe, and has therefore been more challenging in animal models; however, recent work using inhaled radionuclide agents hold promise for small animal research applications [47].

Tumor metabolism has also been widely studied by imaging. Perhaps the best known example is the measurement of regional glucose metabolism using ${ }^{18} \mathrm{~F}$-fluorodeoxyglucose (FDG) PET, which is now routinely used in breast cancer clinical practice to determine the extent of tumor spread and assess response to treatment $[5,25]$. This method can also be readily applied to animal models [48], and can yield detailed physiological information through kinetic analysis of dynamic images $[49,50]$. Other PET radiopharmaceuticals can be used to measure other aspects of metabolism, including regional oxygen consumption and fatty acid metabolism [25]. MRS has also been quite useful in measuring metabolism through ${ }^{1} \mathrm{H}$ spectroscopy to measure levels of lactate and other biochemical species key in metabolism [51] and also through phosphorous spectroscopy to measure concentrations of adenine nucleotides as an indicator of energy metabolism [52]. Other studies in a variety of tumors, especially in brain tumors and prostate cancer, have shown the ability to measure biochemical species in a variety of metabolic pathways - for example, membrane lipids (choline) and metabolic intermediates (citrate) - and have provided improved diagnosis, early measures of response, and insights into pathophysiology [53-58]. The chemical composition of the breast, particularly its high lipid content, provides some challenges for MRS, but recent progress in magnet field strength, acquisition, and processing methods may offer improved capabilities in breast cancer [59].

Aberrant cellular proliferation is a fundamental property of cancer, including breast cancer [60]. Labeled compounds such as ${ }^{14} \mathrm{C}$ - or ${ }^{3} \mathrm{H}$-thmyidine have been an important method for measuring cellular proliferation through sampling, dating back over 40 years [61]. Early work used PET and ${ }^{11} \mathrm{C}$ thymidine to measure tumor proliferation by imaging, and quantitative imaging approaches were validated against in vitro assay gold standards [62]. However, the short half-life of ${ }^{11} \mathrm{C}$ (20 minutes) and the extensive in vivo metabolism of thymidine limit the feasibility of this approach for both animal and patient imaging. More recent work using thymidine analogs labeled with ${ }^{18} \mathrm{~F}$ (half-life 109 minutes) have been developed and undergone considerable advances in recent years $[63,64]$. The most promising of these had been ${ }^{18} \mathrm{~F}$ fluorothymidine (FLT), with notable recent results in both animal and patient breast cancer imaging [65-68]. FLT PET appears especially promising for measuring the early effects of therapy on breast cancer growth, as suggested by recent studies by Kenny and colleagues [66]. This imaging approach had also been validated against in vitro assay of proliferation (reviewed in [63]) and is poised for greater use in both animal research and human clinical trials.

Methods for imaging cell death have also been investigated, but are at an earlier stage of development. Many of these 
have been based upon an extension of Annexin $\mathrm{V}$ staining in vitro, which indicates apoptotic cells through binding to phosphotidyl serines [69]. The molecules are found only on the inner surface of plasma membranes and, therefore, normally not accessible to Annexin V, a peptide, for binding. However, during apoptosis, these molecules are transiently exposed to the extracellular space, allowing binding of Annexin [69]. The earliest studies used 99mTc-annexin and SPECT imaging to measure apoptosis in animal models and patients $[69,70]$. More recently, methods for annexin-based apoptosis imaging have been developed for PET, MRI, optical imaging, and ultrasound [71]. One limitation of this approach has been the transient nature of phosphatidyl serine exposure during cell death, resulting in fairly limited signal for imaging [72]. Other approaches targeted to other aspects of the apoptotic cascade are being investigated [71]. An alternative, but less specific approach has been to use MRI measures of water diffusion through the extracellular space as an indirect measure of tumor cellularity $[19,73]$. Increases in the diffusion coefficient, as an indicator of a decrease in tumor cellularity, have correlated with measures of apoptosis in animal models [19] and response to therapy in early patient studies $[20,73]$. This method has the advantage of being available using existing MRI instrumentation for both animal and patient imaging without the need for imaging probes, but provides a relatively indirect measure of cell death.

Several methods can also measure biosynthesis as an indicator of tumor growth, with approaches targeted to protein synthesis and membrane synthesis. The uptake of labeled amino acids, such as ${ }^{11} \mathrm{C}$-methionine, has been shown to correlate with tumor growth, and changes in uptake provide an early indication of breast cancer response to therapy [74]. This approach, however, is limited by the complex nature of amino acid metabolism pathways, making it difficult to measure protein synthetic rate versus amino acid transport and metabolism [75]. Artificial amino acids have also been tested as indicators of amino acid transport [76].

Proliferating tumor cells also engage in enhanced lipid biosynthesis to provide material needed for cellular membranes [77]. This process can also be assayed through molecular imaging using several different methods. Spurred by results in brain tumor imaging [57], MRS studies of breast cancer have shown increased choline pool sizes to be a feature of breast malignancy $[9,78]$. Interestingly, changes in the choline concentration measured by MRS early in treatment appear to be a marker for early response to therapy, as early as 24 hours after treatment with chemotherapy [22]. These exciting early findings are now being tested in a large prospective cooperative group trial. Lipid metabolism can also be studied by PET using either ${ }^{11} \mathrm{C}$ or ${ }^{18} \mathrm{~F}$ labeled choline, or ${ }^{11} \mathrm{C}$-acetate [79], which enters lipid synthesis from the tricarboxylic acid (TCA) cycle via fatty acid synthetase. Fatty acid synthetase has been show to have increased activity and expression in cancer and may be a target for therapy [80]. This approach has shown considerable promise in other tumors such as prostate cancer [81], including therapeutic response [82], but has not been applied to the same extent in breast cancer [83].

\section{Protein expression: tumor receptors}

The ability to measure the expression of specific proteins that are gene products associated with breast cancer has led to important advances in breast cancer treatment. Examples include the expression of estrogen receptors (ERs), a target for endocrine therapy [84], and HER2, also increasingly a target of tumor-specific treatment [85]. Molecular imaging has also been applied to measuring specific protein expression $[6,24]$. Advantages of imaging include its non-invasiveness, the ability to measure receptor expression in the entire disease burden and thus the ability to avoid sampling error that can occur with heterogeneous receptor expression, and the potential for serial studies of in vivo drug effects on the target. A very practical consideration is that imaging can assess receptor expression at sites that are challenging to sample and assay, for example, bone metastases, where de-calcification can make assay of tumor gene products challenging.

Imaging protein expression, particularly tumor receptors, poses some unique challenges. For receptors, imaging results can be quite sensitive to the molecular quantity of the imaging probe needed to generate the image. Most receptors have high affinity for their ligands and are active at micromolar or nanomolar concentrations of the ligand. Even small molar quantities of the imaging agent may saturate the receptor and limit the ability to visualize receptor expression $[86,87]$. For this reason, molecular imaging of tumor receptors has been most successful to date with radionuclide imaging, PET and SPECT, where it is possible to generate images with nanomolar or picomolar amounts of the imaging probe. For larger molecules, like peptides and monoclonal antibodies, other labels suitable for optical, MR, and ultrasound imaging are possible [6]; however, for small-molecule receptor imaging agents, such as labeled steroids for steroid receptors, radionuclide imaging appears to be the only feasible approach.

The most work to date in this area of breast cancer research has been done for steroid receptors $[6,88]$. Considerable efforts have gone into the development of radiopharmaceuticals for ER imaging, as reviewed in [88-90]. Although a variety of ER imaging agents have been tested, and continue to be developed and tested, the most successful ER imaging radiopharmaceutical to date is 16 alpha-[18 $\mathrm{F}]$-fluoro- 17 betaestradiol (FES) [87,91]. FES has binding characteristics similar to estradiol for both the ER and the transport protein SHBG [92,93]. It can be synthesized with sufficient specific activity that high-quality patient images can be made with injections of less than $5 \mu \mathrm{g}$ of FES [94]. Regional estrogen binding is readily quantified by FES PET, and FES uptake has been validated as a measure of ER expression in breast tumors against ER expression assay of tissue samples by radioligand binding [95] and immunohistochemistry [96]. FES 
Figure 1 (a)

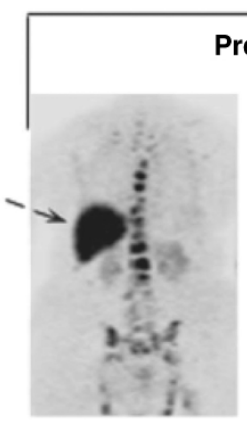

FES

(b)

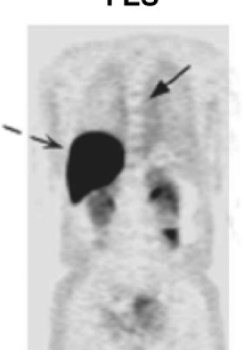

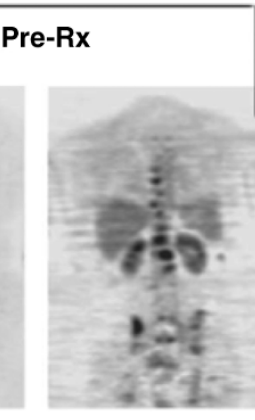

FDG

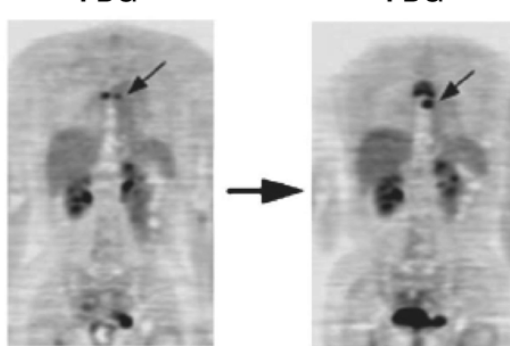

Imaging examples: pre-treatment (Pre-Rx) 16 alpha-[18F]-fluoro17 beta-estradiol positron emission tomography (FES PET; left) and 18F-fluorodeoxyglucose (FDG) PET (middle) scans and follow-up FDG PET post-therapy (Post-Rx; right) are shown. Dashed arrows show normal liver FES uptake. (a) This patient has bone metastasis with robust FES and FDG uptake, and had response at 3 months. (b) This patient has bone metastasis (solid arrow) without FES but with FDG uptake; progressive disease at 6 months. (Reproduced from [94].)

uptake is readily visualized and quantified in primary and metastatic breast cancer [97]. It can identify heterogeneous ER expression, for example, loss of ER expression in metastases arising from ER-expressing primary tumors [94,97]. The level of FES uptake has been shown to be predictive of response to endocrine therapy [94,98], including heavily pre-treated patients (Figure 1). Serial FES PET can also measure the pharmacodynamic effect of drugs on estradiol binding to the ER $[98,99]$, yielding insights into determinants of drug efficacy.

While PET ER imaging had been successful, efforts to image progesterone receptor (PR) have been less successful $[100,101]$. In a study of the PR imaging agent 21 -[18F]fluoro16 alpha-ethyl-19-norprogesterone, uptake was seen in some tumors, but the level of uptake did not correlate with the level of PR expression. This may be in large part due to the relatively low affinity of progestins for the $P R$, with binding affinities that are orders of magnitude lower than those of androgens and androgen receptors and estrogens and ERs [101]. As such, relatively high non-specific binding compared to specific binding of imaging probes may limit their utility for PR imaging. Later studies also showed that the radiopharmaceutical tested was rapidly metabolized in human to a metabolite with poor receptor binding [102], a finding that was not predicted by pre-clinical models. Efforts to develop effective PR imaging agents continue [103].

HER2 (ErbB2) expression in breast cancer has become an important indicator of prognosis and an increasingly important target for therapy [104]. Recent efforts have focused on imaging HER2 expression in breast cancer. The most success and largest number of studies to date used imaging probes based upon immune recognition to image HER2 expression. Specific imaging probes based on radiolabeled antibodies or fragments [105-109], or novel constructs such as affibodies [110,111], have shown success in early studies. Studies using a ${ }^{68} \mathrm{Ga}$-labeled $\mathrm{F}\left(\mathrm{ab} \mathrm{b}^{\prime}\right)_{2}$ fragment of trastuzumab by Smith-Jones and colleagues [112,113] demonstrated the feasibility of measuring regional HER2 expression in murine animal models. The imaging results nicely demonstrated alterations in HER2 expression accompanying experimental therapy using HSP90-directed agents (geldamycin analogs) to disrupt protein chaperoning and reduce HER2 expression $[112,113]$. Studies using ${ }^{131} \mathrm{l}$ - or ${ }^{111} \mathrm{I}$ n-labeled trastuzumab have demonstrated the ability to image tumor expression of HER2 and tumor and normal tissue accumulation of trastuzumab $[108,114,115]$, although there has been some controversy about the significance of uptake in normal tissues prone to trastuzumab toxicity, such as the heart $[108,115]$. Promising early patient studies have also been presented for 89Zr-labeled trastuzumab [116].

For imaging using larger molecules like monoclonal antibodies and fragments, as in the case of HER2 imaging, an even wider range of probes (and therefore imaging modalities) may be possible, including optical, ultrasound, and MR-based probes [117-122]. Koyama [123] demonstrated specific fluorescence imaging of HER2-expressing lung metastasis in an animal model. Others have used nearinfrared imaging of HER2 expression in vitro using gold nanoshell bioconjugates [124] and fluorochrome labeling [125]. Pre-clinical studies using specific antibodies conjugated to gadolinium or magnetic nanoparticles demonstrated the feasibility of MRI antibody imaging in cells [126] and animal models [118]. Early studies of nanoparticle-based ultrasound probes conjugated to HER2-specific antibodies have demonstrated the feasibility of this approach in early in vitro studies and simulated in vivo studies $[119,127]$. The ability to image with multiple modalities is particularly helpful for translating research from the pre-clinical to clinical setting. For example, optical imaging is extremely valuable for smallanimal studies, but has limited utility in patients due to poor tissue penetration for imaging deeper structures. The ability to translate optical imaging findings into PET or MRI imaging in patients, seen in early work for HER2 imaging, holds great promise for facilitating translational research.

\section{Tumor microenvironment}

Molecular imaging provides a unique opportunity to image the tumor microenvironment, which is challenging by more 
invasive means. Tumor hypoxia, an important factor mediating cancer aggressiveness and therapeutic resistance [128,129], has been widely studied by imaging, with some recent studies in breast cancer [130]. Most work has been done using PET imaging and the agent ${ }^{18} \mathrm{~F}$-fluoromisonidazole (FMISO) (Figure 2); however, other PET hypoxia probes have been developed and tested [38]. Other hypoxia imaging methods based upon MRI and optical approaches are at an earlier stage of development, but appear promising [131,132].

Tumor vasculature plays a key role in tumor growth and metastasis, and is also important in the delivery of systemic therapeutic agents. Imaging of tumor vasculature and the delivery of nutrients and drugs has also been an area of interest. Tumor perfusion and capillary transport provide an indirect measure of tumor vasculature and can be imaged by DCE-MRI and PET, which have been effective in measuring tumor response in early studies [16,38,39]. In addition, targeted imaging probes can non-invasively and specifically assess tumor neo-vasculature. PET probes based upon specific labeled peptides that bind to integrins expressed in neovessels have been studied in animals and tested in humans [133,134]. MRI probes have been developed and are at an earlier stage of testing [40]. Such agents may be especially helpful for therapies directed at tumor neovasculature, such as bevacizumab.

Imaging methods to measure nutrient and drug transport have also been developed and tested. For example, the SPECT agent $99 \mathrm{mTC}$-sestamibi, developed for myocardial perfusion imaging, has been shown to be a substrate for the drug efflux transporter P-glycoprotein [135]. Studies in the setting of presurgical chemotherapy showed that the uptake and retention of $99 \mathrm{~m}$ Tc-sestamibi was predictive of response to chemotherapeutic agents that are substrates for P-glycoprotein, such as epirubicin [136]. Somewhat more specific and quantitative probes of P-glycoprotein transport have been developed for PET imaging [137-139]. Macromolecular MRI contrast agents are undergoing testing in patients [140] and may be useful for measuring the delivery of therapeutic agents, such as trastuzumab, that are large molecules where capillary and interstitial transport may pose significant barriers.

\section{Reporter gene imaging and cell labeling}

Advances in cancer biology have led to an increasing array of approaches to breast cancer therapy, including immunotherapy and gene therapy. These advances in turn lead to the need for increasingly sophisticated approaches for imaging to monitor these treatments. An increasing body of work in molecular imaging has therefore been devoted to imaging approaches capable of imaging gene expression and cellular trafficking and survival in vivo [12,82].

Paralleling work done in reporter systems for cell culture, imaging reporter systems have been developed and are increasingly used in animal model research [141-143].
Figure 2

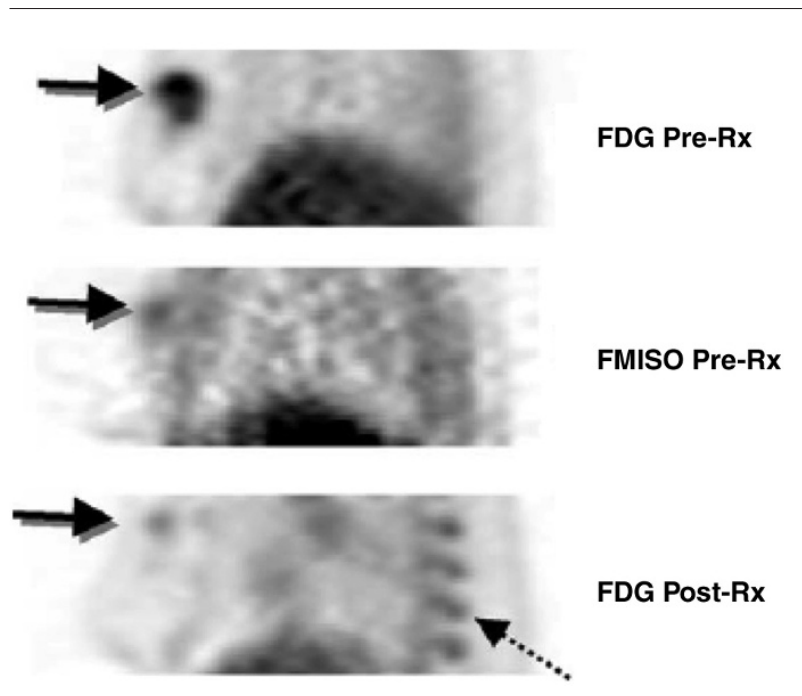

Breast tumor hypoxia as a predictor of drug resistance. A patient with a large, right breast tumor underwent ${ }^{18} \mathrm{~F}$-fluorodeoxyglucose (FDG) and ${ }_{18}^{18}$ F-fluoromisonidazole (FMISO) positron emission tomography (PET) pre-therapy (Pre-Rx; top and middle) and after approximately ten weeks of chemotherapy (Post-Rx; bottom). Images are thick sagittal images, similar to medial-lateral oblique (MLO) mammography views. The pre-therapy FDG study showed uniformly high FDG uptake throughout the tumor. FMISO PET showed uptake suggestive of tumor hypoxia, but only close to the center of the tumor (arrow). Post-therapy images show a dramatic reduction in the extent and intensity of FDG uptake with residual activity in the part of the tumor that had FMISO uptake pre-therapy. Residual viable tumor was found at surgery. Marrow uptake of FDG was also seen post-therapy (dashed arrow) because of granulocyte colony-stimulating factor administered for marrow support as part of the treatment. (Reproduced from [158].)

Reporter imaging can use optical approaches, with reporter genes expressing optically detectable molecules such as green fluorescent protein and firefly luciferase. Optical approaches provide inexpensive, readily available methods for imaging reporter gene expression, and are widely used in current research [144]. Radionuclide methods have also been developed and widely tested in animal models [143]. The most popular approach has been based upon the use of viral thymidine kinase as a reporter gene, combined with labeled probes that are specific substrates for phosphorylation by viral thymidine kinase $[145,146]$. This results in probe trapping and high-contrast, readily quantifiable images [147]. A variety of other radionuclide reporter systems have been used, including the $\mathrm{Nal}$ symporter and radioiodine, receptor expression (for example, dopamine) and receptor binding ligands, and alternative metabolic substrates [148,149]. Some progress has also been made in MRI reporter systems $[150,151]$; however, this work is at an earlier stage than optical and PET approaches.

The development of therapeutic approaches mediated by specific cells - for example, immunotherapy - has generated increasing interest in cell labeling and imaging. Cell labeling 
can be done using non-specific probes, such as ${ }^{111}$ In-oxine and non-targeted iron oxide particles for use in SPECT and MRI, respectively [152]; however, this approach often requires isolation of the cells to assure that only the desired cells are imaged. In cell therapy where molecular manipulation is possible, cells engineered with reporter systems can also be used to provide specific cell labeling that does not require isolation of cells and that remains with the cells through subsequent generations, unlike most nonspecific methods [153]. For immunotherapy, the generation of reporter systems that do not themselves engender an immune response is a challenge and represents an active area of research [154].

\section{Summary and future directions}

Advances in molecular biology create new opportunities for understanding and treating breast cancer, and also create new needs for increasingly sophisticated and quantitative assays. Advances in both technology and molecular biology have led to the capability for molecular imaging, a method for non-invasive and regional assay of in vivo tumor biology. While some molecular imaging methods, most notably SPECT and PET, have begun to be used in patients, many molecular imaging approaches have, as yet, undergone only early testing at a pre-clinical stage. Some methods, such as optical reporter gene imaging, have already become an important part of basic research in animal models. Other approaches, such as PET imaging of tumor receptor expression, look very promising in early patient studies, but have yet to make it to larger clinical trials or clinical practice. Only a relatively few approaches, such as FDG PET, have made their way into clinical practice.

Molecular imaging offers a very powerful tool for translating basic science into clinical benefit. This can happen in several ways. Demonstration that molecular pathways discovered in animal models have relevance to human breast cancer is a critical aspect of breast cancer translational research. Molecular imaging offers a way to assess and quantify pathways in both animal models and patients in order to verify that the pathways behave similarly in both cases. In addition, molecular imaging used to guide drug development and pre-clinical testing can be applied to early clinical studies to provide proof-of-concept, early evidence of efficacy, and a pharmacodynamic measure by which to optimize dosing [155].

There are a number of potential hurdles to translating molecular imaging methods from animals to humans. Some approaches that work well in animals - for example, optical imaging - may not be applicable to patients. Multi-modality imaging approaches - for example, combined optical/MR/PET reporters - may be very helpful in this regard. There may be significant regulatory hurdles to the use of some imaging probes in patients. Recent efforts in collaborations between the $\mathrm{NCl}, \mathrm{FDA}$, and other organizations show promise in helping to facilitate clinical trials of new probes [156].
Echoing trends in molecular breast cancer therapy, clinical trials of molecular imaging may need new approaches to clinical study design, using measures such as prognosis or response as endpoints, rather than sensitivity and specificity for tumor detection [4]. Cooperative groups and scientific organizations have recognized this need and are beginning to address it through a variety of approaches, including multicenter trials [157]. While somewhat daunting, these hurdles are clearly surmountable by close collaboration between breast cancer biologists, clinicians, and imagers. Early results suggest that molecular imaging will play an important role in translational breast cancer research and the care of breast cancer patients and strongly support ongoing efforts in this area of research.

\section{Competing interests}

The author declares that they have no competing interests.

\section{Acknowledgment}

This article is published as part of Breast Cancer Research Volume 10 Supplement 1, 2008: The Scientific Basis of Breast Cancer (http://breast-cancer-research.com/content/10/S1).

\section{References}

1. Hutter $\mathrm{H}$ : Fluorescent reporter methods. Methods Mol Biol 2006, 351:155-173.

2. Blasberg RG: Imaging update: new windows, new views. Clin Cancer Res 2007, 13:3444-3448.

3. Mankoff DA: A definition of molecular imaging. J Nucl Med 2007, 48:18N, 21N.

4. Mankoff DA, O'Sullivan F, Barlow WE, Krohn KA: Molecular imaging research in the outcomes era: measuring outcomes for individualized cancer therapy. Acad Radiol 2007, 14:398405.

5. Benard F, Turcotte E: Imaging in breast cancer: single-photon computed tomography and positron-emission tomography. Breast Cancer Res 2005, 7:153-162.

6. Mankoff DA, Link JM, Linden HM, Sundararajan L, Krohn KA: Tumor receptor imaging. J Nucl Med 2008, in press.

7. Welch DR: Microarrays bring new insights into understanding of breast cancer metastasis to bone. Breast Cancer Res 2004, 6:61-64.

8. Bloch SH, Dayton PA, Ferrara KW: Targeted imaging using ultrasound contrast agents. Progess and opportunities for clinical and research applications. IEEE Eng Med Biol Mag 2004, 23:18-29.

9. Bolan PJ, Nelson MT, Yee D, Garwood M: Imaging in breast cancer: magnetic resonance spectroscopy. Breast Cancer Res 2005, 7:149-152.

10. Lehman $C D$, Schnall MD: Imaging in breast cancer: magnetic resonance imaging. Breast Cancer Res 2005, 7:215-219.

11. Mankoff $D$ : Imaging in breast cancer - breast cancer imaging revisited. Breast Cancer Res 2005, 7:276-278.

12. Berger F, Gambhir SS: Recent advances in imaging endogenous or transferred gene expression utilizing radionuclide technologies in living subjects: applications to breast cancer. Breast Cancer Res 2001, 3:28-35.

13. Saslow D, Boetes $C$, Burke W, Harms $S$, Leach MO, Lehman CD, Morris E, Pisano E, Schnall M, Sener S, Smith RA, Warner E, Yaffe M, Andrews KS, Russell CA; American Cancer Society Breast Cancer Advisory Group: American Cancer Society guidelines for breast screening with MRI as an adjunct to mammography. CA Cancer J Clin 2007, 57:75-89.

14. Lehman CD, Gatsonis C, Kuhl CK, Hendrick RE, Pisano ED Hanna L, Peacock S, Smazal SF, Maki DD, Julian TB, DePeri ER, Bluemke DA, Schnall MD; ACRIN Trial 6667 Investigators Group: MRI evaluation of the contralateral breast in women with recently diagnosed breast cancer. N Engl J Med 2007, 356: 1295-1303. 
15. Padhani AR, Hayes C, Assersohn L, Powles T, Makris A, Suckling $\mathrm{J}$, Leach MO, Husband JE: Prediction of clinicopathologic response of breast cancer to primary chemotherapy at contrast-enhanced MR imaging: initial clinical results. Radiology 2006, 239:361-374.

16. Wedam SB, Low JA, Yang SX, Chow CK, Choyke P, Danforth D, Hewitt SM, Berman A, Steinberg SM, Liewehr DJ, Plehn J, Doshi A, Thomasson D, McCarthy N, Koeppen H, Sherman M, Zujewski J, Camphausen K, Chen H, Swain SM: Antiangiogenic and antitumor effects of bevacizumab in patients with inflammatory and locally advanced breast cancer. J Clin Oncol 2006, 24: 769-777.

17. Yankeelov TE, Lepage M, Chakravarthy A, Broome EE, Niermann KJ, Kelley MC, Meszoely I, Mayer IA, Herman CR, McManus K, Price RR, Gore JC: Integration of quantitative DCE-MRI and ADC mapping to monitor treatment response in human breast cancer: initial results. Magn Reson Imaging 2007, 25:1-13.

18. Sosnovik DE, Weissleder R: Emerging concepts in molecular MRI. Curr Opin Biotechnol 2007, 18:4-10.

19. Morse DL, Galons JP, Payne CM, Jennings DL, Day S, Xia G, Gillies RJ: MRI-measured water mobility increases in response to chemotherapy via multiple cell-death mechanisms. NMR Biomed 2007, 20:602-614.

20. Theilmann RJ, Borders R, Trouard TP, Xia G, Outwater E, RangerMoore J, Gillies RJ, Stopeck A: Changes in water mobility measured by diffusion MRI predict response of metastatic breast cancer to chemotherapy. Neoplasia 2004, 6:831-837.

21. Gillies RJ, Morse DL: In vivo magnetic resonance spectroscopy in cancer. Annu Rev Biomed Eng 2005, 7:287-326.

22. Meisamy S, Bolan PJ, Baker EH, Bliss RL, Gulbahce E, Everson LI, Nelson MT, Emory TH, Tuttle TM, Yee D, Garwood M: Neoadjuvant chemotherapy of locally advanced breast cancer: predicting response with in vivo (1)H NMR spectroscopy - a pilot study at 4T. Radiology 2004, 233:424-431.

23. Mankoff DA, Eubank WB: Current and future use of positron emission tomography (PET) in breast cancer. J Mammary Gland Biol Neoplasia 2006, 11:125-136.

24. Quon A, Gambhir SS: FDG-PET and beyond: molecular breast cancer imaging. J Clin Oncol 2005, 23:1664-1673.

25. Mankoff DA, Eary JF, Link JM, Muzi M, Rajendran JG, Spence AM, Krohn KA: Tumor-specific positron emission tomography imaging in patients: $\left[{ }^{18} \mathrm{~F}\right]$ fluorodeoxyglucose and beyond. Clin Cancer Res 2007, 13:3460-3469.

26. Cherry SR: The 2006 Henry N. Wagner Lecture: Of mice and men (and positrons) - advances in PET imaging technology. $J$ Nucl Med 2006, 47:1735-1745.

27. Rosen EL, Turkington TG, Soo MS, Baker JA, Coleman RE: Detection of primary breast carcinoma with a dedicated, large-field-of-view FDG PET mammography device: initial experience. Radiology 2005, 234:527-534.

28. Alessio $A M$, Kinahan PE, Cheng PM, Vesselle $H$, Karp JS: $\mathrm{PET} / \mathrm{CT}$ scanner instrumentation, challenges, and solutions. Radiol Clin North Am 2004, 42:1017-32, vii.

29. Tromberg BJ, Cerussi A, Shah N, Compton M, Durkin A, Hsiang $D$, Butler J, Mehta R: Imaging in breast cancer: diffuse optics in breast cancer: detecting tumors in pre-menopausal women and monitoring neoadjuvant chemotherapy. Breast Cancer Res 2005, 7:279-285.

30. Mahmood U: Near infrared optical applications in molecular imaging. Earlier, more accurate assessment of disease presence, disease course, and efficacy of disease treatment. IEEE Eng Med Biol Mag 2004, 23:58-66.

31. Henriquez NV, van Overveld PG, Que I, Buijs JT, Bachelier R, Kaijzel EL, Löwik CW, Clezardin P, van der Pluijm G: Advances in optical imaging and novel model systems for cancer metastasis research. Clin Exp Metastasis 2007, 24:699-705

32. Mendelson EB: Problem-solving ultrasound. Radiol Clin North Am 2004, 42:909-18, vii.

33. Ferrara K, Pollard R, Borden M: Ultrasound microbubble contrast agents: fundamentals and application to gene and drug delivery. Annu Rev Biomed Eng 2007, 9:415-447.

34. Huang SW, Kim K, Witte RS, Olafsson R, O'Donnell M: Inducing and imaging thermal strain using a single ultrasound linear array. IEEE Trans Ultrason Ferroelectr Freq Control 2007, 54: 1718-1720.

35. Brenner RJ, Parisky Y: Alternative breast-imaging approaches. Radiol Clin North Am 2007, 45:907-923, viii.
36. Chodosh LA, Cardiff RD: In vivo imaging of the mammary gland: the shape of things to come. J Mammary Gland Biol Neoplasia 2006, 11:101-102.

37. Kety SS: Basic principles for the quantitative estimation of regional cerebral blood flow. Res Publ Assoc Res Nerv Ment Dis 1985, 63:1-7.

38. Rajendran JG, Mankoff DA: Positron emission tomography imaging of hypoxia and blood flow in tumors. In Cancer Drug Discovery and Development: In vivo Imaging of Cancer. Edited by Shields AF, Price P. Totowa, NJ: Humana Press; 2006:47-71.

39. Mankoff DA, Dunnwald LK, Gralow JR, Ellis GK, Schubert EK, Tseng J, Lawton TJ, Linden HM, Livingston RB: Changes in blood flow and metabolism in locally advanced breast cancer treated with neoadjuvant chemotherapy. J Nucl Med 2003, 44: 1806-1814

40. Barrett T, Brechbiel M, Bernardo M, Choyke PL: MRI of tumor angiogenesis. J Magn Reson Imaging 2007, 26:235-249.

41. Choyke PL, Dwyer AJ, Knopp MV: Functional tumor imaging with dynamic contrast-enhanced magnetic resonance imaging. J Magn Reson Imaging 2003, 17:509-520.

42. Hylton N: Dynamic contrast-enhanced magnetic resonance imaging as an imaging biomarker. J Clin Oncol 2006, 24: 3293-3298.

43. Padhani AR, Leach MO: Antivascular cancer treatments: functional assessments by dynamic contrast-enhanced magnetic resonance imaging. Abdom Imaging 2005, 30:324-341.

44. Strecker R, Scheffler K, Buchert M, Mross K, Drevs J, Hennig J: DCE-MRI in clinical trials: data acquisition techniques and analysis methods. Int J Clin Pharmacol Ther 2003, 41:603-605.

45. Kiessling F, Morgenstern B, Zhang C: Contrast agents and applications to assess tumor angiogenesis in vivo by magnetic resonance imaging. Curr Med Chem 2007, 14:77-91.

46. Leach MO, Brindle KM, Evelhoch JL, Griffiths JR, Horsman MR, Jackson A, Jayson G, Judson IR, Knopp MV, Maxwell RJ, Mclntyre D, Padhani AR, Price P, Rathbone R, Rustin G, Tofts PS, Tozer GM, Vennart W, Waterton JC, Williams SR, Workman P: Assessment of antiangiogenic and antivascular therapeutics using MRI: recommendations for appropriate methodology for clinical trials. Br J Radio/ 2003, 76(Spec No. 1):S87-91.

47. Miller KD, Miller M, Mehrotra S, Agarwal B, Mock BH, Zheng OH, Badve S, Hutchins GD, Sledge GW Jr: A physiologic imaging pilot study of breast cancer treated with AZD2171. Clin Cancer Res 2006, 12:281-288.

48. Aliaga A, Rousseau JA, Cadorette J, Croteau E, van Lier JE, Lecomte R, Bénard $F$ : A small animal positron emission tomography study of the effect of chemotherapy and hormonal therapy on the uptake of 2-deoxy-2-[F-18]fluoro-Dglucose in murine models of breast cancer. Mol Imaging Biol 2007, 9:144-150.

49. Krak NC, Hoekstra OS, Lammertsma AA: Measuring response to chemotherapy in locally advanced breast cancer: methodological considerations. Eur J Nucl Med Mol Imaging 2004, 31 (Suppl 1):S103-111.

50. Mankoff DA, Muzi M, Krohn KA: Quantitative positron emission tomography imaging to measure tumor response to therapy: what is the best method? Mol Imaging Bio/ 2003, 5:281-285.

51. Matsumura A, Isobe T, Takano S, Kawamura H, Anno I: Non-invasive quantification of lactate by proton MR spectroscopy and its clinical applications. Clin Neurol Neurosurg 2005, 107:379384.

52. Arias-Mendoza F, Payne GS, Zakian KL, Schwarz AJ, Stubbs M, Stoyanova R, Ballon D, Howe FA, Koutcher JA, Leach MO, Griffiths JR, Heerschap A, Glickson JD, Nelson SJ, Evelhoch JL, Charles HC, Brown TR: In vivo 31P MR spectral patterns and reproducibility in cancer patients studied in a multi-institutional trial. NMR Biomed 2006, 19:504-512.

53. Di Costanzo A, Trojsi F, Tosetti M, Schirmer T, Lechner SM, Popolizio T, Scarabino T: Proton MR spectroscopy of the brain at $3 \mathrm{~T}$ : an update. Eur Radiol 2007, 17:1651-1662.

54. Leach MO: Magnetic resonance spectroscopy (MRS) in the investigation of cancer at The Royal Marsden Hospital and The Institute of Cancer Research. Phys Med Biol 2006, 51: R61-82.

55. Mountford C, Lean C, Malycha P, Russell P: Proton spectroscopy provides accurate pathology on biopsy and in vivo. $J$ Magn Reson Imaging 2006, 24:459-477.

56. Mueller-Lisse UG, Scherr MK: Proton MR spectroscopy of the 
prostate. Eur J Radio/ 2007, 63:351-360.

57. Nelson SJ: Multivoxel magnetic resonance spectroscopy of brain tumors. Mol Cancer Ther 2003, 2:497-507.

58. Rosen $Y$, Lenkinski RE: Recent advances in magnetic resonance neurospectroscopy. Neurotherapeutics 2007, 4:330-345.

59. Haddadin IS, Mclntosh A, Meisamy S, Corum C, Snyder AL, Powell NJ, Nelson MT, Yee D, Garwood M, Bolan PJ: Metabolite quantification and high-field MRS in breast cancer. NMR Biomed 2007 [Epub ahead of print].

60. Tannock IF: Cell proliferation. In The Basic Science of Oncology. Edited by Tannock IF, Hill RP. New York: McGraw-Hill; 1992:154177.

61. Cleaver JE: Thymidine metabolism and cell kinetics. Frontiers Biol 1967, 6:43-100.

62. Mankoff DA, Shields AF, Link JM, Graham MM, Muzi M, Peterson LM, Eary JF, Krohn KA: Kinetic analysis of $2-\left[{ }^{11} \mathrm{C}\right]$ thymidine PET imaging studies: validation studies. J Nucl Med 1999, 40:614624.

63. Mankoff DA, Shields AF, Krohn KA: PET imaging of cellular proliferation. Radiol Clin North Am 2005, 43:153-167.

64. Shields AF, Grierson JR, Dohmen BM, Machulla HJ, Stayanoff JC, Lawhorn-Crews JM, Obradovich JE, Muzik O, Mangner TJ: Imaging proliferation in vivo with [F-18]FLT and positron emission tomography. Nat Med 1998, 4:1334-1336.

65. Been LB, Elsinga PH, de Vries J, Cobben DC, Jager PL, Hoekstra $\mathrm{HJ}$, Suurmeijer AJ: Positron emission tomography in patients with breast cancer using (18)F-3'-deoxy-3'-fluoro-I-thymidine ((18)F-FLT)-a pilot study. Eur J Surg Onco/ 2006, 32:39-43.

66. Kenny L, Coombes RC, Vigushin DM, Al-Nahhas A, Shousha S, Aboagye EO: Imaging early changes in proliferation at 1 week post chemotherapy: a pilot study in breast cancer patients with 3'-deoxy-3'-[18 F]fluorothymidine positron emission tomography. Eur J Nucl Med Mol Imaging 2007, 34:1339-1347.

67. Pio BS, Park CK, Pietras R, Hsueh WA, Satyamurthy N, Pegram MD, Czernin J, Phelps ME, Silverman DH: Usefulness of 3'-[F18]fluoro-3'-deoxythymidine with positron emission tomography in predicting breast cancer response to therapy. Mol Imaging Biol 2006, 8:36-42

68. Smyczek-Gargya B, Fersis N, Dittmann H, Vogel U, Reischl G, Machulla HJ, Wallwiener D, Bares R, Dohmen BM: PET with [18 F]fluorothymidine for imaging of primary breast cancer: a pilot study. Eur J Nucl Med Mol Imaging 2004, 31:720-724.

69. Blankenberg F, Ohtsuki K, Strauss HW: Dying a thousand deaths. Radionuclide imaging of apoptosis. Q J Nucl Med 1999, 43:170-176.

70. van de Wiele C, Lahorte C, Vermeersch H, Loose D, Mervillie K, Steinmetz ND, Vanderheyden JL, Cuvelier CA, Slegers G, Dierck RA: Quantitative tumor apoptosis imaging using technetium99m-HYNIC annexin V single photon emission computed tomography. J Clin Oncol 2003, 21:3483-3487.

71. Schoenberger J, Bauer J, Moosbauer J, Eilles C, Grimm D: Innovative strategies in in vivo apoptosis imaging. Curr Med Chem 2008, 15:187-194.

72. Tait JF, Smith C, Blankenberg FG: Structural requirements for

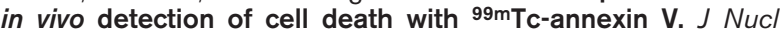
Med 2005, 46:807-815

73. Lee KC, Moffat BA, Schott AF, Layman R, Ellingworth S, Juliar R, Khan AP, Helvie M, Meyer CR, Chenevert TL, Rehemtulla A, Ross $\mathrm{BD}$ : Prospective early response imaging biomarker for neoadjuvant breast cancer chemotherapy. Clin Cancer Res 2007, 13: $443-450$

74. Jansson $\mathrm{T}$, Westlin JE, Ahlstrom $\mathrm{H}$, Lilja A, Langstrom $\mathrm{B}$, Bergh J: Positron emission tomography studies in patients with locally advanced and/or metastatic breast cancer: a method for early therapy evaluation? J Clin Oncol 1995, 13:1470-1477.

75. Ishiwata K, Enomoto K, Sasaki T, Elsinga PH, Senda M, Okazumi $\mathrm{S}$, Isono K, Paans AM, Vaalburg W: A feasibility study on L-[1carbon-11]tyrosine and L-[methyl-carbon-11]methionine to assess liver protein synthesis by PET. J Nucl Med 1996, 37:279-285.

76. Hübner KF, Thie JA, Smith GT, Kabalka GW, Keller IB, Kliefoth $\mathrm{AB}$, Campbell SK, Buonocore E: Positron emission tomography (PET) with 1-aminocyclobutane-1-[(11)C]carboxylic acid (1[(11)C]-ACBC) for detecting recurrent brain tumors. Clin Positron Imaging 1998, 1:165-173.

77. Glunde K, Jacobs MA, Bhujwalla ZM: Choline metabolism in cancer: implications for diagnosis and therapy. Expert Rev Mol
Diagn 2006, 6:821-829

78. Stanwell $P$, Mountford C: In vivo proton MR spectroscopy of the breast. Radiographics 2007, 27(Suppl 1):S253-266.

79. Groves AM, Win T, Haim SB, Ell PJ: Non-[18F]FDG PET in clinical oncology. Lancet Oncol 2007, 8:822-830.

80. Lupu R, Menendez JA: Targeting fatty acid synthase in breast and endometrial cancer: An alternative to selective estrogen receptor modulators? Endocrinology 2006, 147:4056-4066.

81. Powles T, Murray I, Brock C, Oliver T, Avril N: Molecular positron emission tomography and $\mathrm{PET} / \mathrm{CT}$ imaging in urological malignancies. Eur Urol 2007, 51:1511-1520, discussion 15201521

82. Yu EY, Mankoff DA: Positron emission tomography imaging as a cancer biomarker. Expert Rev Mol Diagn 2007, 7:659-672.

83. Zheng $\mathrm{OH}$, Stone $\mathrm{KL}$, Mock BH, Miller KD, Fei X, Liu X, Wang J$\mathrm{Q}$, Glick-Wilson BE, Sledge GW, Hutchins GD: $\left.{ }^{11} \mathrm{C}\right]$ Choline as a potential PET marker for imaging of breast cancer athymic mice. Nucl Med Biol 2002, 29:803-807

84. Jordan VC, Brodie AM: Development and evolution of therapies targeted to the estrogen receptor for the treatment and prevention of breast cancer. Steroids 2007, 72:7-25.

85. Slamon DJ, Leyland-Jones B, Shak S, Fuchs H, Paton V, Bajamonde A, Fleming T, Eiermann W, Wolter J, Pegram M, Baselga J, Norton L: Use of chemotherapy plus a monoclonal antibody against HER2 for metastatic breast cancer that overexpresses HER2. N Engl J Med 2001, 344:783-792.

86. Katzenellenbogen J: The pharmacology of steroid radiopharmaceuticals: specific and non-specific binding and uptake selectivity. In Radiopharmaceuticals: Chemistry and Pharmacology. Edited by Nunn A. New York: Marcel Dekker; 1992:297-331.

87. Katzenellenbogen JA, Welch MJ, Dehdashti F: The development of estrogen and progestin radiopharmaceuticals for imaging breast cancer. Anticancer Res 1997, 17:1573-1576.

88. Katzenellenbogen JA: Designing steroid receptor-based radiotracers to image breast and prostate tumors. J NuCl Med 1995, 36(6 Suppl):8S-13S.

89. Rijks LJ, Busemann Sokole E, Stabin MG, de Bruin K, Janssen $A G$, van Royen EA: Biodistribution and dosimetry of iodine123-labelled Z-MIVE: an oestrogen receptor radioligand for breast cancer imaging. Eur J Nucl Med 1998, 25:40-47.

90. Zielinski JE, Larner JM, Hoffer PB, Hochberg RB: The synthesis of 11 beta-methoxy-[16 alpha-123|] iodoestradiol and its interaction with the estrogen receptor in vivo and in vitro. J NuCl Med 1989, 30:209-215.

91. Cummins $\mathrm{CH}$ : Radiolabeled steroidal estrogens in cancer research. Steroids 1993, 58:245-259.

92. Kiesewetter DO, Kilbourn MR, Landvatter SW, Heiman DF Katzenellenbogen JA, Welch MJ: Preparation of four fluorine18-labeled estrogens and their selective uptakes in target tissues of immature rats. J Nucl Med 1984, 25:1212-1221.

93. Tewson TJ, Mankoff DA, Peterson LM, Woo I, Petra P: Interactions of 16alpha-[18F]-fluoroestradiol (FES) with sex steroid binding protein (SBP). Nucl Med Biol 1999, 26:905-913.

94. Linden HM, Stekhova SA, Link JM, Gralow JR, Livingston RB, Ellis GK, Petra PH, Peterson LM, Schubert EK, Dunnwald LK, Krohn $\mathrm{KA}$, Mankoff DA: Quantitative fluoroestradiol positron emission tomography imaging predicts response to endocrine treatment in breast cancer. J Clin Oncol 2006, 24:2793-2799.

95. Mintun MA, Welch MJ, Siegel BA, Mathias CJ, Brodack JW, McGuire AH, Katzenellenbogen JA: Breast cancer: PET imaging of estrogen receptors. Radiology 1988, 169:45-48.

96. Peterson LM, Mankoff DA, Lawton TJ, Yagle KJ, Schubert EK, Stekhova S, et al: Quantitative imaging of estrogen receptor expression of breast cancer with PET and [F-18']-fluorestradiol. J Nucl Med 2008, in press.

97. Dehdashti F, Mortimer JE, Siegel BA, Griffeth LK, Bonasera TJ, Fusselman MJ, Detert DD, Cutler PD, Katzenellenbogen JA, Welch MJ: Positron tomographic assessment of estrogen receptors in breast cancer: comparison with FDG-PET and in vitro receptor assays. J Nucl Med 1995, 36:1766-1774.

98. Mortimer JE, Dehdashti F, Siegel BA, Trinkaus K, Katzenellenbogen JA, Welch MJ: Metabolic flare: indicator of hormone responsiveness in advanced breast cancer. J Clin Oncol 2001, 19:2797-2803.

99. Linden HM, Link JM, Stekhova S, Livingston RB, Gralow JR, Ellis GK, Schubert EK, Peterson LM, Krohn KA, Mankoff DA: Serial ${ }^{18} \mathrm{~F}$-fluoroestradiol positron emission tomography (FES PET) 
measures estrogen receptor binding during endocrine therapy. Breast Cancer Res Treat 2005.

100. Dehdashti F, McGuire AH, Brocklin HFV, Siegel BA, Andriole DP, Griffeth LK, Pomper MG, Katzenellenbogen JA, Welch MJ: Assessment of 21-[18 F]fluoro-16 alpha-ethyl-19-nonprogesterone as a positron-emitting radiopharmaceutical for the detection of progestin receptors in human breast carcinomas. J Nucl Med 1991, 32:1532-1537.

101. Jonson SD, Welch MJ: PET imaging of breast cancer with fluorine-18 radiolabeled estrogens and progestins. $\mathrm{Q} J \mathrm{NuCl}$ Med 1998, 42:8-17.

102. Verhagen A, Studeny M, Luurtsema G, Visser GM, De Goeij CC, Sluyser M, Nieweg OE, Van der Ploeg E, Go KG, Vaalburg W: Metabolism of a [18F]fluorine labeled progestin (21[18F]fluoro-16 alpha-ethyl-19-norprogesterone) in humans: a clue for future investigations. Nucl Med Biol 1994, 21:941952.

103. Zhou D, Carlson KE, Katzenellenbogen JA, Welch MJ: Bromineand iodine-substituted 16alpha,17alpha-dioxolane progestins for breast tumor imaging and radiotherapy: synthesis and receptor binding affinity. $J$ Med Chem 2006, 49:4737-4744.

104. Harris L, Fritsche H, Mennel R, Norton L, Ravdin P, Taube S, Somerfield MR, Hayes DF, Bast RC Jr; American Society of Clinical Oncology: American Society of Clinical Oncology 2007 update of recommendations for the use of tumor markers in breast cancer. J Clin Oncol 2007, 25:5287-5312.

105. Bogdanov A Jr, Kang HW, Querol M, Pretorius PH, Yudina A: Synthesis and testing of a binary catalytic system for imaging of signal amplification in vivo. Bioconjug Chem 2007, 18:11231130 .

106. Cai W, Chen K, He L, Cao Q, Koong A, Chen X: Quantitative PET of EGFR expression in xenograft-bearing mice using (64)Cu-labeled cetuximab, a chimeric anti-EGFR monoclonal antibody. Eur J Nucl Med Mol Imaging 2007, 34:850-858.

107. Orlova A, Magnusson M, Eriksson TL, Nilsson M, Larsson B, Höidén-Guthenberg I, Widström C, Carlsson J, Tolmachev V, Ståhl S, Nilsson FY: Tumor imaging using a picomolar affinity HER2 binding affibody molecule. Cancer Res 2006, 66:43394348.

108. Perik PJ, Lub-De Hooge MN, Gietema JA, van der Graaf WT, de Korte MA, Jonkman S, Kosterink JG, van Veldhuisen DJ, Sleijfer DT, Jager PL, de Vries EG: Indium-111-labeled trastuzumab scintigraphy in patients with human epidermal growth factor receptor 2-positive metastatic breast cancer. J Clin Oncol 2006, 24:2276-2282.

109. Pnwar P, Iznaga-Escobar N, Mishra P, Srivastava V, Sharma RK, Chandra R, Mishra AK: Radiolabeling and biological evaluation of DOTA-Ph-Al derivative conjugated to anti-EGFR antibody ior egf $/ \mathrm{r} 3$ for targeted tumor imaging and therapy. Cancer Biol Ther 2005, 4:854-860.

110. Engfeldt T, Orlova A, Tran T, Bruskin A, Widström C, Karlström $A E$, Tolmachev V: Imaging of HER2-expressing tumours using a synthetic Affibody molecule containing the $99 \mathrm{~m}$ Tc-chelating mercaptoacetyl-glycyl-glycyl-glycyl (MAG3) sequence. Eur J Nucl Med Mol Imaging 2007, 34:722-733.

111. Tolmachev V, Nilsson FY, Widström C, Andersson K, Rosik D, Gedda L, Wennborg A, Orlova A: ${ }^{111}$ In-benzyl-DTPA-ZHER2:342, an affibody-based conjugate for in vivo imaging of HER2 expression in malignant tumors. J Nucl Med 2006, 47:846853.

112. Smith-Jones PM, Solit D, Afroze F, Rosen N, Larson SM: Early tumor response to Hsp90 therapy using HER2 PET: comparison with 18F-FDG PET. J Nucl Med 2006, 47:793-796.

113. Smith-Jones PM, Solit DB, Akhurst T, Afroze F, Rosen N, Larson SM: Imaging the pharmacodynamics of HER2 degradation in response to Hsp90 inhibitors. Nat Biotechnol 2004, 22:701706.

114. Costantini DL, Chan C, Cai Z, Vallis KA, Reilly RM: ${ }^{111}$ In-labeled trastuzumab (Herceptin) modified with nuclear localization sequences (NLS): an auger electron-emitting radiotherapeutic agent for HER2/neu-amplified breast cancer. J Nucl Med 2007, 48:1357-1368.

115. de Korte MA, de Vries EG, Lub-de Hooge MN, Jager PL, Gietema JA, van der Graaf WT, Sluiter W, van Veldhuisen D, Suter T, Sleijfer D: (111)Indium-trastuzumab visualises myocardial human epidermal growth factor receptor 2 expression shortly after anthracycline treatment but not during heart failure: A clue to uncover the mechanisms of trastuzumab-related cardiotoxicity. Eur J Cancer 2007, 43:2046-2051.

116. Dijkers E, Lub-de Hooge MN, Kosterink JG, Jager PL, Brouwers AH, Perk LR, van Dongen GA, de Vries EG: Characterization of 89Zf-trastuzumab for clinical HER2 immunoPET imaging. $J$ Clin Oncol 2007, 25:140s.

117. Achilefu S: Lighting up tumors with receptor-specific optical molecular probes. Technol Cancer Res Treat 2004, 3:393-409.

118. Artemov D, Mori N, Ravi R, Bhujwalla ZM: Magnetic resonance molecular imaging of the HER-2/neu receptor. Cancer Res 2003, 63:2723-2727.

119. Lee JH, Huh YM, Jun YW, Seo JW, Jang JT, Song HT, Kim S, Cho EJ, Yoon HG, Suh JS, Cheon J: Artificially engineered magnetic nanoparticles for ultra-sensitive molecular imaging. Nat Med 2007, 13:95-99.

120. Liu J, Li J, Rosol TJ, Pan X, Voorhees JL: Biodegradable nanoparticles for targeted ultrasound imaging of breast cancer cells in vitro. Phys Med Biol 2007, 52:4739-4747.

121. Rosenthal EL, Kulbersh BD, King T, Chaudhuri TR, Zinn KR: Use of fluorescent labeled anti-epidermal growth factor receptor antibody to image head and neck squamous cell carcinoma xenografts. Mol Cancer Ther 2007, 6:1230-1238.

122. Winnard $P \mathrm{Jr}$, Raman $\mathrm{V}$ : Real time non-invasive imaging of receptor-ligand interactions in vivo. J Cell Biochem 2003, 90: 454-463.

123. Koyama Y, Hama Y, Urano Y, Nguyen DM, Choyke PL, Kobayashi $\mathrm{H}$ : Spectral fluorescence molecular imaging of lung metastases targeting HER2/neu. Clin Cancer Res 2007, 13:29362945

124. Loo C, Lowery A, Halas N, West J, Drezek R: Immunotargeted nanoshells for integrated cancer imaging and therapy. Nano Lett 2005, 5:709-711.

125. Hilger I, Leistner $Y$, Berndt A, Fritsche C, Haas KM, Kosmehl $H$ Kaiser WA: Near-infrared fluorescence imaging of HER-2 protein over-expression in tumour cells. Eur Radiol 2004, 14: 1124-1129.

126. Funovics MA, Kapeller B, Hoeller C, Su HS, Kunstfeld R, Puig S, Macfelda K: MR imaging of the her2/neu and 9.2.27 tumor antigens using immunospecific contrast agents. Magn Reson Imaging 2004, 22:843-850.

127. Copland JA, Eghtedari M, Popov VL, Kotov N, Mamedova N, Motamedi M, Oraevsky A: Bioconjugated gold nanoparticles as a molecular based contrast agent: implications for imaging of deep tumors using optoacoustic tomography. Mol Imaging Biol 2004, 6:341-349.

128. Sutherland R: Tumor hypoxia and gene expression. Acta Oncologica 1998, 37:567-574.

129. Teicher Ba: Hypoxia and drug resistance. Cancer Metastasis Rev 1994, 13:139-168.

130. Rajendran JG, Mankoff DA, O'Sullivan F, Peterson LM, Schwartz DL, Conrad EU, Spence AM, Muzi M, Farwell DG, Krohn KA: Hypoxia and glucose metabolism in malignant tumors: evaluation by [ $\left.{ }^{18} \mathrm{~F}\right]$ fluoromisonidazole and [18F]fluorodeoxyglucose positron emission tomography imaging. Clin Cancer Res 2004, 10:2245-2252.

131. Padhani AR, Krohn KA, Lewis JS, Alber M: Imaging oxygenation of human tumours. Eur Radiol 2007, 17:861-872.

132. Tatum JL, Kelloff GJ, Gillies RJ, Arbeit JM, Brown JM, Chao KS, Chapman JD, Eckelman WC, Fyles AW, Giaccia AJ, Hill RP, Koch CJ, Krishna MC, Krohn KA, Lewis JS, Mason RP, Melillo G, Padhani AR, Powis G, Rajendran JG, Reba R, Robinson SP, Semenza GL, Swartz HM, Vaupel P, Yang D, Croft B, Hoffman J, Liu G, Stone H, Sullivan D: Hypoxia: importance in tumor biology, noninvasive measurement by imaging, and value of its measurement in the management of cancer therapy. Int $J$ Radiat Biol 2006, 82:699-757.

133. Beer AJ, Niemeyer M, Carlsen J, Sarbia M, Nährig J, Watzlowik P, Wester HJ, Harbeck N, Schwaiger M: Patterns of \{alpha\}v\{beta\} 3 expression in primary and metastatic human breast cancer as shown by $18 \mathrm{~F}$-galacto-RGD PET. J Nucl Med 2008, 49:255-259.

134. Beer AJ, Haubner R, Sarbia M, Goebel M, Luderschmidt S, Grosu AL, Schnell O, Niemeyer M, Kessler H, Wester HJ, Weber WA, Schwaiger $M$ : Positron emission tomography using [18 $\mathrm{F}]$ Galacto-RGD identifies the level of integrin alpha(v)beta3 expression in man. Clin Cancer Res 2006, 12:3942-3949.

135. Piwnica-Worms D, Chiu ML, Budding M, Kronauge JF, Kramer 
RA, Croop JM: Functional imaging of multidrug-resistant Pglycoprotein with an organotechnetium complex. Cancer Res 1993, 53:977-984.

136. Ciarmiello A, Vecchio SD, Silvestro P, Potenta M, Carriero M, Thomas R, Botti G, D'Aiuto G, Salvatore M: Tumor clearance of technetium $99 \mathrm{~m}$-sestamibi as a predictor of response to neoadjuvant chemotherapy for locally advanced breast cancer. J Clin Oncol 1998, 16:1677-1683.

137. Hendrikse $\mathrm{NH}$, de Vries EG, Franssen EJ, Vaalburg W, van der Graaf WT: In vivo measurement of [11C]verapamil kinetics in human tissues. Eur J Clin Pharmacol 2001, 56:827-829.

138. Kurdziel KA, Kalen JD, Hirsch JI, Wilson JD, Agarwal R, Barrett D, Bear HD, McCumiskey JF: Imaging multidrug resistance with 4[18F]fluoropaclitaxel. Nucl Med Bio/ 2007, 34:823-831.

139. Sasongko L, Link JM, Muzi M, Mankoff DA, Yang X, Collier AC, Shoner SC, Unadkat JD: Imaging P-glycoprotein transport activity at the human blood-brain barrier with positron emission tomography. Clin Pharmacol Ther 2005, 77:503-514.

140. Mohs AM, Lu ZR: Gadolinium(III)-based blood-pool contrast agents for magnetic resonance imaging: status and clinical potential. Expert Opin Drug Deliv 2007, 4:149-164.

141. Serganova I, Blasberg R: Reporter gene imaging: potential impact on therapy. Nucl Med Biol 2005, 32:763-780.

142. Yaghoubi SS, Barrio JR, Namavari M, Satyamurthy N, Phelps ME, Herschman HR, Gambhir SS: Imaging progress of herpes simplex virus type 1 thymidine kinase suicide gene therapy in living subjects with positron emission tomography. Cancer Gene Ther 2005, 12:329-339.

143. Gambhir SS: Molecular imaging of cancer with positron emission tomography. Nat Rev Cancer 2002, 2:683-693.

144. Ntziachristos V: Fluorescence molecular imaging. Annu Rev Biomed Eng 2006, 8:1-33.

145. Blasberg RG, Tjuvajev JG: Herpes simplex virus thymidine kinase as a marker/reporter gene for PET imaging of gene therapy. Q J Nucl Med 1999, 43:163-169.

146. Gambhir SS, Barrio JR, Herschman HR, Phelps ME: Assays for noninvasive imaging of reporter gene expression. Nucl Med Biol 1999, 26:481-490.

147. Yaghoubi SS, Gambhir SS: Measuring herpes simplex virus thymidine kinase reporter gene expression in vitro. Nat Protoc 2006, 1:2137-2142.

148. Blasberg RG: In vivo molecular-genetic imaging: multi-modality nuclear and optical combinations. Nucl Med Biol 2003, 30: 879-888.

149. Groot-Wassink T, Aboagye EO, Wang Y, Lemoine NR, Reader AJ, Vassaux G: Quantitative imaging of $\mathrm{Na} / \mathrm{I}$ symporter transgene expression using positron emission tomography in the living animal. Mol Ther 2004, 9:436-442.

150. Lyons SK: Advances in imaging mouse tumour models in vivo. J Pathol 2005, 205:194-205.

151. Gilad AA, Winnard PT Jr, van Zijl PC, Bulte JW: Developing MR reporter genes: promises and pitfalls. NMR Biomed 2007, 20: 275-290.

152. Zhang SJ, Wu JC: Comparison of imaging techniques for tracking cardiac stem cell therapy. J Nucl Med 2007, 48:19161919.

153. Acton PD, Zhou R: Imaging reporter genes for cell tracking with PET and SPECT. Q J Nucl Med Mol Imaging 2005, 49:349360.

154. Knutson KL, Almand B, Mankoff DA, Schiffman K, Disis ML: Adoptive T-cell therapy for the treatment of solid tumours. Expert Opin Biol Ther 2002, 2:55-66.

155. Aboagye EO, Price PM: Use of positron emission tomography in anticancer drug development. Invest New Drugs 2003, 21: 169-181.

156. Kelloff GJ, Krohn KA, Larson SM, Weissleder R, Mankoff DA, Hoffman JM, Link JM, Guyton KZ, Eckelman WC, Scher HI, O'Shaughnessy J, Cheson BD, Sigman CC, Tatum JL, Mills GQ, Sullivan DC, Woodcock J: The progress and promise of molecular imaging probes in oncologic drug development. Clin Cancer Res 2005, 11:7967-7985.

157. Aberle DR, Chiles C, Gatsonis C, Hillman BJ, Johnson CD, McClennan BL, Mitchell DG, Pisano ED, Schnall MD, Sorensen AG; American College of Radiology Imaging Network: Imaging and cancer: research strategy of the American College of Radiology Imaging Network. Radiology 2005, 235:741-751.

158. Eubank WB, Mankoff DA: Evolving role of positron emission tomography in breast cancer imaging. Semin Nucl Med 2005, 35:84-99. 